\title{
Acute carbon monoxide poisoning in a regional hospital in Hong Kong: historical cohort study
}

\author{
MY Chan *, Thomas TS Au, KS Leung, WW Yan
}

\section{A B S T R A C T}

Objectives: This study aimed to describe the clinical profiles of all patients with carbon monoxide poisoning admitted to a regional hospital in order to enhance the vigilance of health care professionals for delayed neurological sequelae associated with carbon monoxide poisoning and to identify the prognostic factors associated with their development. This study also aimed to assess the impact of hyperbaric oxygen therapy on the development of delayed neurological sequelae in these patients.

Methods: This was a historical cohort study in which all patients with a diagnosis of carbon monoxide poisoning managed in a regional hospital in Hong Kong from 12 February 2003 to 8 November 2013 were recruited. Main outcome measures included delayed neurological sequelae.

Results: Of the clinical profiles of 93 patients analysed, 24 patients received hyperbaric oxygen therapy and did not develop delayed neurological sequelae. Seven patients who did not receive hyperbaric oxygen therapy developed delayed neurological sequelae. Comparison of groups with and without delayed neurological sequelae (excluding hyperbaric oxygen therapy-treated patients) revealed that loss of consciousness $(\mathrm{P}=0.038)$, Glasgow Coma Scale score of $3(\mathrm{P}=0.012)$, elevated troponin level $(\mathrm{P}<0.001)$, higher creatine

This article was published on 15 Jan 2016 at www.hkmj.org. kinase level $(\mathrm{P}=0.008)$, and intubation requirement $(\mathrm{P}=0.007)$ were possible prognostic factors for the development of delayed neurological sequelae.
Conclusion: Although not statistically significant, this study showed a 100\% protective effect of hyperbaric oxygen therapy against development of severe delayed neurological sequelae in patients with severe carbon monoxide poisoning. Further study with better study design is warranted. Loss of consciousness, low Glasgow Coma Scale score, intubation requirement, elevated troponin and higher creatine kinase levels were possible prognostic factors for development of delayed neurological sequelae in patients with severe carbon monoxide poisoning. A well-defined treatment protocol, appropriate follow-up duration and neuropsychiatric tests together with a hospital-based hyperbaric chamber are recommended for management of patients with severe carbon monoxide poisoning.

\section{Hong Kong Med J 2016;22:46-55}

DOI: 10.12809/hkmj144529

${ }^{1}$ MY Chan *, FHKCEM, FHKAM (Emergency Medicine)

1 TTS Au, FHKCEM, FHKAM (Emergency Medicine)

${ }^{1}$ KS Leung, FHKCEM, FHKAM (Emergency Medicine)

${ }^{2}$ WW Yan, FHKAM (Medicine)

1 Accident and Emergency Department

2 Department of Intensive Care Unit

Pamela Youde Nethersole Eastern Hospital, Chai Wan, Hong Kong

* Corresponding author: odin@ha.org.hk

New knowledge added by this study

- Loss of consciousness, low Glasgow Coma Scale score, intubation requirement, and elevated troponin and creatine kinase levels were possible prognostic factors for development of delayed neurological sequelae in patients with severe carbon monoxide poisoning.

- Presentation of neurological sequelae can be delayed from a few months to a year.

Implications for clinical practice or policy

- A hospital-based hyperbaric oxygen chamber is recommended to decrease the burden of off-site therapy for patients with severe carbon monoxide poisoning and to facilitate timely treatment in a safe environment in Hong Kong.

- A well-defined treatment protocol with adequate follow-up and neuropsychiatric tests are recommended for patients with severe carbon monoxide poisoning.

\section{Introduction}

Carbon monoxide $(\mathrm{CO})$ poisoning was not common in Hong Kong prior to 1998. The first reported case of $\mathrm{CO}$ poisoning from suicidal charcoal burning occurred in 1998 in Hong Kong. A middle-aged woman who was a chemical engineer invented this method of suicide that became the third most common method in Hong Kong within 2 months 
of her death and the associated publicity. ${ }^{1}$ To date, suicidal charcoal burning remains the top cause of suicidal death in this crowded and stressful city.

Victims of $\mathrm{CO}$ poisoning are sent to either the mortuary or public hospitals in Hong Kong. Most patients who are admitted to hospitals eventually survive with supportive management but there is no standard treatment protocol. Treatment regimens varied in different hospitals at different times. Cases of delayed neurological sequelae (DNS) secondary to $\mathrm{CO}$ poisoning are well reported in the literature..$^{2-6}$ In a Cochrane review in 2011, it was stated "It is possible that some patients, particularly those with more severe poisoning, may derive benefit from [hyperbaric oxygen] treatment, but this remains unproven." Hyperbaric oxygen therapy (HBOT) is now a standard treatment option in many developed countries and China for selected patients with severe $\mathrm{CO}$ poisoning.

According to Lam et al in 2006, ${ }^{8}$ the incidence of DNS in Hong Kong was 3.4\%, which was much lower than other reported rates of $10 \%$ to $30 \% .^{2-7}$ The overall incidence of DNS is likely to have been underdiagnosed and under-reported in Hong Kong because of a lack of detailed neurological examination and neuropsychiatric tests during acute management and follow-up sessions.

Pamela Youde Nethersole Eastern Hospital (PYNEH) has been one of the pioneer hospitals to support HBOT for CO poisoning in Hong Kong. The lack of a hospital-based hyperbaric oxygen chamber in Hospital Authority (HA) hospitals in Hong Kong has limited the number of HBOT sessions administered to patients with $\mathrm{CO}$ poisoning, particularly those with severe poisoning, because of the risks associated with patient management at a remote site deprived of medical support. Special arrangements would currently be required to send a patient to Ngong Shuen Chau for HBOT. To date, PYNEH has been the principal advocator of HBOT for $\mathrm{CO}$ poisoning patients in Hong Kong and has treated the largest number of severe cases.

This 10-year retrospective study aimed to describe the clinical profile of all $\mathrm{CO}$ poisoning patients admitted to PYNEH with the aim of improving vigilance of health care professionals for DNS associated with CO poisoning and identifying the prognostic factors for their development. The study also aimed to assess the impact of HBOT on the development of DNS in these patients.

\section{Methods}

\section{Data collection}

Patients with a diagnosis of $\mathrm{CO}$ poisoning documented in the Clinical Management System (CMS) of the HA and being managed at PYNEH between 12 February 2003 and 8 November 2013 were

\section{急性一氧化碳中毒在香港一所分區醫院的 歷史隊列研究 \\ 陳銘賢、歐德信、梁啟城、殷榮華}

目的：描述所有入住一所分區醫院的一氧化碳中毒患者的臨床情 況, 從而加強醫療界人士對一氧化碳中毒與遲發性神經系統後遺症 （DNS）的警惕性和識別DNS的預後因素。本研究也旨在評估高壓氧 治療對DNS發展的影響。

方法：這項歷史隊列研究納入由 2003 年2月 12 日至2013年11月 8 日期 間, 於香港一所分區醫院確診一氧化碳中毒的患者。主要結果測量包 括DNS。

結果 : 分析了93名符合研究納入標準的患者, 其中 24 人接受高壓氧治 療而沒有出現DNS。沒有接受高壓氧治療的患者中，7人出現DNS。 比較DNS和非DNS組別（不包括高壓氧治療的患者）後發現, 對發展 DNS的可能預後因素分別為：昏倒（ $\mathrm{P}=0.038 ）$ 、格拉斯哥昏迷指數

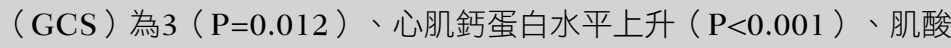
激水平上升（ $\mathrm{P}=0.008 ）$ 以及氣管插管（ $\mathrm{P}=0.007 ）$

結論：儘管統計上不顯著, 本研究顯示高壓氧治療對嚴重一氧化碳中 毒患者提供了 $100 \%$ 防止DNS的保護作用。須進一步使用更好的研究 設計來探討這問題。昏倒、低GCS、氣管插管以及提升心肌肌鉟蛋白 和肌酸激水平是可能的DNS預後因素。在此建議要治療嚴重一氧化碳 中毒的病人, 須先定立一個明確的治療方案再加上適當的精神情緒測 試和覆診時間表及一所位於醫院內的高壓氧氣艙。

included. This entailed recourse to the Clinical Data Analysis and Reporting System (CDARS) of the HA. Relevant accident and emergency notes, radiological reports, laboratory results, and discharge summaries were retrieved. The following were recorded where available: age, sex, systolic and diastolic blood pressure, heart rate, temperature, electrocardiogram (ECG), Glasgow Coma Scale (GCS) score at presentation, endotracheal intubation, history of or presence of loss of consciousness (LOC), blood tests for carboxyhaemoglobin $(\mathrm{COHb})$ level, creatine kinase (CK) level, troponin (Tn) level, HBOT, complications from HBOT, development of DNS, co-ingestion, suicidal methods and intention.

\section{Case selection of hyperbaric oxygen therapy in our hospital}

The use of HBOT for severe $\mathrm{CO}$ poisoning was advocated in the Intensive Care Unit of PYNEH after 2008. The need for HBOT in patients who presented with $\mathrm{CO}$ poisoning was judged on a case-by-case basis. The indications for and contra-indications to $\mathrm{HBOT}$ for patients with severe $\mathrm{CO}$ poisoning are summarised in Table 1 . The treatment protocol of HBOT for CO poisoning at Ngong Shuen Chau is shown in the Figure. Most patients were given 
TABLE I. Indications and contra-indications for HBOT in patients with severe CO poisoning, with reference to the Undersea and Hyperbaric Medical Society

\begin{tabular}{|c|c|}
\hline Indication/contra-indication & Description \\
\hline $\begin{array}{l}\text { Indications of HBOT for patients } \\
\text { with severe CO poisoning } \\
\text { features* }\end{array}$ & $\begin{array}{l}\text { 1. LOC or history of LOC suspected to be caused by CO poisoning } \\
\text { 2. Evidence of myocardial ischaemia with typical chest symptoms or electrocardiogram changes } \\
\text { 3. COHb level }>25 \% \text { on admission (not absolute) } \\
\text { 4. Pregnancy }\end{array}$ \\
\hline $\begin{array}{l}\text { Absolute contra-indications for } \\
\text { HBOT }\end{array}$ & $\begin{array}{l}\text { 1. Untreated pneumothorax } \\
\text { 2. Refusal by patient or their proxies } \\
\text { 3. High requirement of oxygen concentration (eg } \mathrm{FiO}_{2} \geq 0.5 \text {, mechanical ventilation is not a contra-indication) } \\
\text { 4. Some selected medications } \\
\text { - Doxorubicin-cardiotoxicity may occur } \\
\text { - Cisplatinum-wound healing may be impaired } \\
\text { - Disulfiram-blocks the production of superoxide dismutase, which protects against oxygen toxicity } \\
\text { - Mafenide acetate-wound healing may be impaired }\end{array}$ \\
\hline $\begin{array}{l}\text { Relative contra-indications for } \\
\text { HBOT }\end{array}$ & $\begin{array}{l}\text { 1. Haemodynamically unstable (need for vasopressor/inotropes and at risk during transportation) } \\
\text { 2. Asthma (medication required to control the condition) } \\
\text { 3. Chronic obstructive pulmonary disease/bullous emphysema } \\
\text { 4. Claustrophobia, emotionally unstable or seizures (medications, eg benzodiazepines, for controlling } \\
\text { 5. Ear or sinus surgery } \\
\text { 6. Optic neuritis } \\
\text { 7. Recent thoracic surgery } \\
\text { 8. Upper respiratory infections } \\
\text { 9. Pacemakers (their technical specifications should be reviewed prior to treatment to avoid deformation) }\end{array}$ \\
\hline
\end{tabular}

Abbreviations: $\mathrm{CO}=$ carbon monoxide; $\mathrm{COHb}=$ carboxyhaemoglobin; $\mathrm{FiO}_{2}=$ fraction of inspired oxygen; $\mathrm{HBOT}=$ hyperbaric oxygen therapy; $\mathrm{LOC}=$ loss of consciousness; PYNEH = Pamela Youde Nethersole Eastern Hospital

* Adopted in intensive care unit of PYNEH since 2008

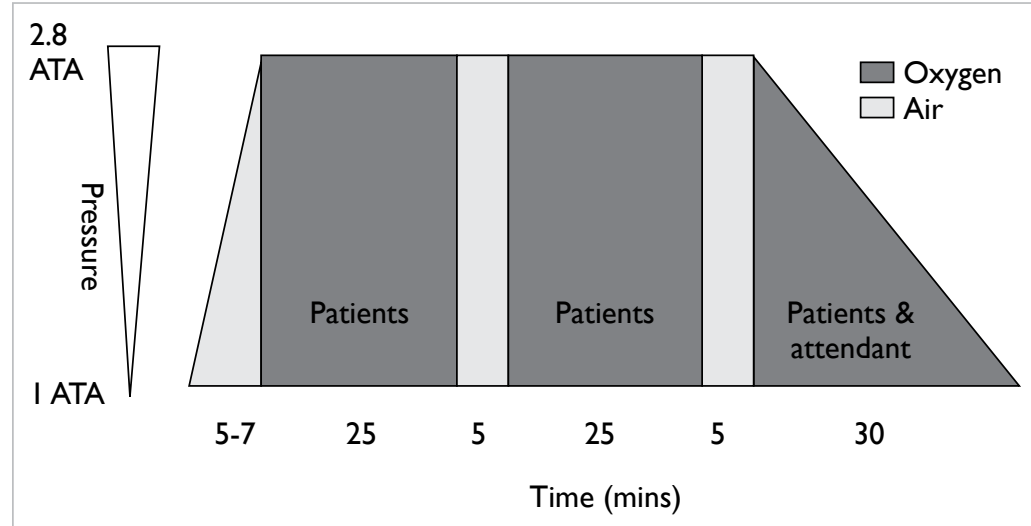

FIG. Treatment protocol of HBOT for carbon monoxide poisoning in Ngong Shuen Chau (Royal Navy table 60)

Abbreviations: ATA = atmosphere absolute; HBOT = hyperbaric oxygen therapy three sessions of HBOT over 3 consecutive days. Exceptions included refusal by patients or their relatives, or operational difficulties.

\section{Statistical analyses}

Univariate analysis for the development of DNS was done by the Fisher's exact test for dichotomous variables and the Mann-Whitney $U$ test for continuous variables, with respect to the following factors: age, sex, source of $\mathrm{CO}$, cause of $\mathrm{CO}$ poisoning, systolic and diastolic blood pressure, heart rate, temperature, GCS, GCS $=3$, LOC, $\mathrm{COHb}$ level, $\mathrm{COHb}$ level $>25 \%$, Tn level, Tn level $>0.03 \mathrm{ng} /$ $\mathrm{mL}$, CK level, CK level >200 IU/L, ECG ischaemic changes, endotracheal intubation, co-ingestion, and HBOT. The distribution of Tn and CK levels showed positive skewness, thus the parameters were expressed in terms of means and standard deviations, as well as medians and interquartile ranges. All statistical analyses were performed using the Statistical Package for the Social Sciences (Windows version 22.0; SPSS Inc, Chicago [IL], US). The level of statistical significance was set at 0.05 .

\section{Results}

A total of 95 cases were diagnosed with $\mathrm{CO}$ poisoning during the study period. One case was excluded because the patient presented with cardiac arrest and succumbed shortly after admission before any blood tests were performed. Another case of DNS that resulted in convulsion, dysphasia, and double incontinence was excluded as the acute $\mathrm{CO}$ poisoning event occurred in Manila. The remaining 93 cases were recruited for analysis. All the demographic data and blood test results are shown in Table 2. Among the 93 patients analysed, 24 received HBOT; DNS had not developed in this group of patients. Nonetheless DNS had developed in seven patients who did not undergo HBOT.

\section{Patients with delayed neurological sequelae}

Among the seven cases of DNS where patients did not undergo HBOT, no formal follow-up had 
TABLE 2. Demographic data and investigation results of all cases and comparative univariate analysis between the DNS and nonDNS groups

\begin{tabular}{|c|c|c|c|c|}
\hline & \multicolumn{3}{|c|}{ Mean \pm SD or No. $(\%)$ of patients* } & \multirow[t]{2}{*}{$P$ value } \\
\hline & All cases $(n=93)$ & DNS $(n=7)$ & Non-DNS ( $n=86)$ & \\
\hline Age (years) & $35.6 \pm 13$ & $36.9 \pm 16$ & $35.5 \pm 13$ & 0.531 \\
\hline Male & $46.0 \%$ & $57.1 \%$ & $46.5 \%$ & 0.700 \\
\hline \multicolumn{5}{|l|}{ Source of CO } \\
\hline Charcoal burning & $80(86.0 \%)$ & $7(100 \%)$ & $73(84.9 \%)$ & 0.588 \\
\hline Fire accident & $6(6.5 \%)$ & 0 & $6(7.0 \%)$ & \\
\hline LPG leakage/bathing & $4(4.3 \%)$ & 0 & $4(4.7 \%)$ & \\
\hline Town gas inhalation & $3(3.2 \%)$ & 0 & $3(3.5 \%)$ & \\
\hline Cause & & & & 1.000 \\
\hline Suicidal & $83(89.2 \%)$ & $7(100 \%)$ & $76(88.4 \%)$ & \\
\hline Accidental & $10(10.8 \%)$ & 0 & $10(11.6 \%)$ & \\
\hline Systolic BP (mm Hg) & $126 \pm 23$ & $117 \pm 35$ & $127 \pm 22$ & 0.101 \\
\hline Diastolic BP (mm Hg) & $76 \pm 14$ & $70 \pm 15$ & $77 \pm 14$ & 0.185 \\
\hline Heart rate (beats/min) & $101 \pm 19$ & $104 \pm 23$ & $100 \pm 19$ & 0.347 \\
\hline Temperature $\left({ }^{\circ} \mathrm{C}\right)$ & $36.7 \pm 0.8$ & $37.6 \pm 1.4$ & $36.6 \pm 0.7$ & 0.106 \\
\hline GCS & $11.5 \pm 4.4$ & $7.6 \pm 5.0$ & $11.8 \pm 4.2$ & 0.023 \\
\hline $\mathrm{GCS}=3$ & $11(11.8 \%)$ & $3(42.9 \%)$ & $8(9.3 \%)$ & 0.034 \\
\hline LOC & $51(54.8 \%)$ & $6(85.7 \%)$ & $45(52.3 \%)$ & 0.123 \\
\hline $\mathrm{COHb}$ level (\%) & $21.8 \pm 14.5$ & $20.3 \pm 16.2$ & $21.6 \pm 14.1$ & 0.942 \\
\hline $\mathrm{COHb}$ level >25\% & $38(40.9 \%)$ & $3(42.9 \%)$ & $35(40.7 \%)$ & 1.000 \\
\hline \multicolumn{5}{|l|}{ Troponin $(\mathrm{ng} / \mathrm{mL})$} \\
\hline Mean \pm SD & $0.69 \pm 1.8$ & $2.56 \pm 1.3$ & $0.52 \pm 1.8$ & 0.001 \\
\hline Median, IQR & $0.02,0.40$ & $2.72,2.47$ & $0.02,0.35$ & \\
\hline Troponin $>0.03 \mathrm{ng} / \mathrm{mL}$ & $22 / 49(44.9 \%)$ & $4 / 4(100 \%)$ & $18 / 45(40.0 \%)$ & 0.035 \\
\hline \multicolumn{5}{|l|}{ CK (IU/L) [n=61] } \\
\hline Mean \pm SD & $2368 \pm 9565$ & $1830 \pm 1527$ & $2427 \pm 10070$ & 0.026 \\
\hline Median, IQR & 200,1270 & 1370,3141 & 177,669 & \\
\hline CK >200 IU/L & $30 / 61(49.2 \%)$ & $5 / 6(83.3 \%)$ & $25 / 55(45.5 \%)$ & 0.104 \\
\hline ECG changes & $9 / 90(10.0 \%)$ & $1 / 6(16.7 \%)$ & 8/84 (9.5\%) & 0.197 \\
\hline Endotracheal intubation & $25(26.9 \%)$ & $4(57.1 \%)$ & $21(24.4 \%)$ & 0.081 \\
\hline Co-ingestion & $42(45.2 \%)$ & $4(57.1 \%)$ & $38(44.2 \%)$ & 0.700 \\
\hline $\mathrm{HBO}$ treatment & 24 (25.8\%) & 0 & 24 (27.9\%) & 0.184 \\
\hline
\end{tabular}

Abbreviations: $\mathrm{BP}=$ blood pressure; $\mathrm{CK}=$ creatine kinase; $\mathrm{CO}=$ carbon monoxide; $\mathrm{COHb}=$ carboxyhaemoglobin; $\mathrm{DNS}=$ delayed neurological sequelae; ECG = electrocardiogram; GCS = Glasgow Coma Scale score; HBO = hyperbaric oxygen; IQR = interquartile range; $\mathrm{LOC}=$ loss of consciousness; $\mathrm{LPG}=$ liquefied petroleum gas; $\mathrm{SD}=$ standard deviation

* Unless otherwise indicated

been arranged to detect DNS associated with $\mathrm{CO}$ poisoning. Nonetheless, DNS was diagnosed in these cases because the neurological symptoms became evident during the same episode of hospitalisation, or the neurological symptoms were detected by their caretakers after the initial hospitalisation. The clinical profiles of these DNS patients with radiological confirmation are summarised in Table 3.

\section{Hyperbaric oxygen therapy}

There were 24 patients treated with HBOT. Their mean age was 36.3 (range, 19-61) years and the male-to-female ratio was 1:1. Of these 24 patients, the source of CO poisoning in 23 (96\%) was charcoal burning and one $(4 \%)$ patient had accidental $\mathrm{CO}$ poisoning due to leakage of a liquid petroleum gas combustion system while bathing. In 21 (87.5\%) 
TABLE 3. Descriptive summary of the seven patients with DNS

\begin{tabular}{|c|c|c|c|c|c|c|c|c|c|}
\hline $\begin{array}{l}\text { Pa- } \\
\text { tient } \\
\text { No. }\end{array}$ & $\begin{array}{c}\text { Age } \\
\text { (years)/ } \\
\text { sex }\end{array}$ & COHb (\%) & $\begin{array}{c}\text { Day of } \\
\text { discharge }\end{array}$ & $\begin{array}{l}\text { Presen- } \\
\text { tation time } \\
\text { of DNS }\end{array}$ & DNS feature & $\begin{array}{c}\text { Hospital } \\
\text { stay for DNS }\end{array}$ & Radiological findings & $\begin{array}{l}\text { Outcome as } \\
\text { of December } \\
2014\end{array}$ & $\begin{array}{l}\text { Reason for } \\
\text { no HBOT }\end{array}$ \\
\hline 1 & $31 / F$ & 38.9 & Day 1 & 1 Year & Convulsion & 5 Days & $\begin{array}{l}\text { CT brain showed } \\
\text { hypodensities in globus } \\
\text { pallidus }\end{array}$ & $\begin{array}{l}\text { Independent } \\
\text { ADL }\end{array}$ & Before 2008 \\
\hline 2 & $30 / \mathrm{M}$ & 34.3 & Day 10 & 16 Days & $\begin{array}{l}\text { Dull, convulsion, } \\
\text { bedbound with } \\
\text { sacral sore }\end{array}$ & 6 Months & $\begin{array}{l}\text { MRI showed globus pallidus } \\
\text { lesions with periventricular } \\
\text { deep white matter T2 signal }\end{array}$ & $\begin{array}{l}\text { Unstable gait, } \\
\text { wheelchair } \\
\text { for outdoor } \\
\text { activities }\end{array}$ & Before 2008 \\
\hline 3 & $24 / M$ & 39 & Day 17 & 1 Month & $\begin{array}{l}\text { Unsteady gait, } \\
\text { parkinsonism, } \\
\text { incontinence; } \\
\text { MMSE=13/30 }\end{array}$ & 3 Months & $\begin{array}{l}\text { CT brain showed diffuse } \\
\text { bilateral symmetrical } \\
\text { hypodense areas in } \\
\text { cerebral hemispheres. } \\
\text { Subtle bilateral pallidal } \\
\text { hypodensities }\end{array}$ & $\begin{array}{l}\text { Independent } \\
\text { ADL }\end{array}$ & Before 2008 \\
\hline 4 & $26 / F$ & $\begin{array}{l}5.3 \text { After } \\
\mathrm{O}_{2} \text { given } \\
\text { for hours }\end{array}$ & Day 5 & 10 Months & $\begin{array}{l}\text { Parkinsonism, } \\
\text { memory and } \\
\text { functional } \\
\text { deterioration with } \\
\text { irritable mood; } \\
\text { MMSE=27/30 }\end{array}$ & 2 Months & $\begin{array}{l}\text { CT brain showed hypodense } \\
\text { lesions in bilateral basal } \\
\text { ganglia }\end{array}$ & $\begin{array}{l}\text { Independent } \\
\text { ADL }\end{array}$ & Before 2008 \\
\hline 5 & $24 / M$ & $\begin{array}{l}12.8 \text { After } \\
\mathrm{O}_{2} \text { given } \\
\text { for hours }\end{array}$ & $\mathrm{N} / \mathrm{A}$ & 1 Month & $\begin{array}{l}\text { Unsteady gait, } \\
\text { walked with } \\
\text { frame }\end{array}$ & 1 Year & $\begin{array}{l}\text { MRI brain showed patchy } \\
\text { areas of non-enhancing } \\
\text { T1 isointense to mildly } \\
\text { hyperintense, T2 and flair } \\
\text { hyperintense signal changes } \\
\text { over bilateral frontal and } \\
\text { occipital subcortical and } \\
\text { deep white mater, bilateral } \\
\text { globus pallidus, and bilateral } \\
\text { cerebral peduncles }\end{array}$ & $\begin{array}{l}\text { Live in hostel, } \\
\text { left upper limb } \\
\text { contracture, } \\
\text { bilateral } \\
\text { lower limb } \\
\text { involuntary } \\
\text { movement }\end{array}$ & $\begin{array}{l}\text { History of } \\
\text { recurrent } \\
\text { pneumothorax }\end{array}$ \\
\hline 6 & $55 / \mathrm{M}$ & $\begin{array}{l}4.7 \text { After } \\
\mathrm{O}_{2} \text { given } \\
\text { for hours }\end{array}$ & N/A & 2 Weeks & $\begin{array}{l}\text { Bedbound tube } \\
\text { feeding and non- } \\
\text { communicable; } \\
\text { MMSE=8/30, } \\
\text { convulsion }\end{array}$ & $\begin{array}{l}2 \text { Months } \\
\text { rehabilitation } \\
\text { hospital and 1- } \\
\text { year old-aged } \\
\text { home care }\end{array}$ & $\begin{array}{l}\text { MRI brain showed } \\
\text { T2 hyperintensities } \\
\text { - over bilateral cerebral } \\
\text { hemispheric white matter }\end{array}$ & $\begin{array}{l}\text { Bedbound with } \\
\text { features of } \\
\text { parkinsonism }\end{array}$ & $\begin{array}{l}\text { No HBOT } \\
\text { in Ruttonjee } \\
\text { Hospital }\end{array}$ \\
\hline 7 & $65 / F$ & $\begin{array}{l}\text { 7.3 After } \\
\mathrm{O}_{2} \text { given } \\
\text { for hours }\end{array}$ & Day 21 & 1 Month & $\begin{array}{l}\text { Dull and slow } \\
\text { in response; } \\
\text { MMSE=13/30 }\end{array}$ & 4 Months & $\begin{array}{l}\text { MRI brain showed } \\
\text { periventricular T2/FLAIR } \\
\text { hyperintense foci involving } \\
\text { bilateral white matter }\end{array}$ & MMSE $=26 / 30$ & $\begin{array}{l}\text { Refused } \\
\text { HBOT }\end{array}$ \\
\hline
\end{tabular}

Abbreviations: $\mathrm{ADL}=$ activity of daily living; $\mathrm{COHb}=$ carboxyhaemoglobin; $\mathrm{CT}=$ computed tomography; DNS = delayed neurological sequelae; FLAIR = fluid-attenuated inversion recovery; HBOT = hyperbaric oxygen therapy; MMSE = Mini-Mental State Examination score; MRI = magnetic resonance imaging; $\mathrm{N} / \mathrm{A}=$ not applicable; $\mathrm{O}_{2}=$ oxygen

* Refer to the time after $\mathrm{CO}$ poisoning

patients, LOC developed prior to admission. There were four (17\%) patients with GCS score of $15 / 15$ and $20(83 \%)$ patients with GCS score of $3-14 / 15$. The mean COHb level was 29.2\% (range, 3.3\%-48.7\%); Tn level was elevated in 15 (78.9\%) of 19 cases; CK level was elevated in 13 (65\%) of 20 cases; ECG showed acute ischaemic changes in five (21\%) cases. No DNS developed in patients treated with HBOT.

\section{Complications of hyperbaric oxygen therapy}

Complications secondary to HBOT developed in three patients: perforated tympanic membrane in one patient, left otitis media related to grommet insertion before HBOT in one, and barotrauma with left ear pain due to blockage of the myringotomy site in another who required repeated myringotomy. Nonetheless all patients completed the whole course of HBOT without long-term sequelae.

\section{Patients with carbon monoxide poisoning and acute ischaemic electrocardiographic changes}

The most common ischaemic change on ECG was ST segment depression. Acute ischaemic changes were evident in nine patients. Their mean age was 42 (range, 27-61) years, and the male-to-female ratio was $5: 4$. Eight (89\%) cases committed suicide by charcoal burning and one $(11 \%)$ patient had $\mathrm{CO}$ poisoning due to an accidental fire. In seven (78\%) patients, LOC developed prior to admission. There 
was one (11\%) patient with GCS score of $15 / 15$, and eight (89\%) patients with score of 3-14/15. The mean COHb level was $24.3 \%$ (range, 3.9\%-48.7\%); Tn level was elevated in seven (78\%) patients and CK level was elevated in four (44\%). The HBOT was offered to five (56\%) patients with ischaemic ECG changes and DNS developed in one (11\%) patient.

Detailed descriptive analysis of the GCS of all patients showed a bimodal distribution with one mode at GCS of 3 points and the other at GCS of 15 points. Thus, GCS of 3 points was used as an indicator of severe $\mathrm{CO}$ poisoning. One of the clinical indications for HBOT was COHb level of $>25 \%$ and served as another indicator of severe $\mathrm{CO}$ poisoning. Thus, GCS of 3 and COHb level of $>25 \%$ were tested as possible prognostic factors for DNS.

Due to variations in the clinical management, blood tests for Tn and CK were not carried out in all patients. Elevated Tn was defined as serum Tn level of $>0.03 \mathrm{ng} / \mathrm{mL}$ on admission. Level of Tn was not checked throughout the clinical course in 44 patients but was elevated in 22 and normal in 27. Elevated CK was defined as serum CK level of $>200 \mathrm{IU} / \mathrm{L}$. This value was used for simplicity as the upper limit of normal is $180 \mathrm{IU} / \mathrm{L}$ in our laboratory. Level of CK was not checked throughout the clinical course in 32 patients but was raised in 30 and normal in 31 .

Comparative statistical analysis showed that the DNS group had significantly lower GCS score, a greater proportion of patients with GCS of 3 points, and higher levels of Tn (Table 2). However, CK levels were significantly higher in the non-DNS than in the DNS group, although the proportions of elevated CK were not statistically significant. The higher CK level in the non-DNS group can be explained by one single case of severe $\mathrm{CO}$ poisoning with prolonged LOC, pressure sores, and compartment syndrome leading to a supremely high CK level of 73560 IU/L on admission. The result is better illustrated by comparison of the median and interquartile range as shown in Table 2. The association between the possible benefit of HBOT and DNS was not

TABLE 4. Comparative univariate analysis of DNS and non-DNS groups, with HBOT-treated patients excluded

\begin{tabular}{|c|c|c|c|}
\hline & \multicolumn{2}{|c|}{ Mean \pm SD or No. (\%) of patients* } & \multirow[t]{2}{*}{ P value } \\
\hline & DNS (n=7) & Non-DNS excluding HBOT $(n=62)$ & \\
\hline Age (years) & $36.9 \pm 16$ & $35.2 \pm 13$ & 0.544 \\
\hline Male & $57.1 \%$ & $43.5 \%$ & 0.692 \\
\hline Systolic BP (mm Hg) & $117 \pm 35$ & $130 \pm 21$ & 0.057 \\
\hline Diastolic BP (mm Hg) & $70 \pm 15$ & $77 \pm 14$ & 0.169 \\
\hline Heart rate (beats/min) & $104 \pm 23$ & $99 \pm 17$ & 0.301 \\
\hline Temperature $\left({ }^{\circ} \mathrm{C}\right)$ & $37.6 \pm 1.4$ & $36.7 \pm 0.6$ & 0.137 \\
\hline LOC & $6(85.7 \%)$ & $24(38.7 \%)$ & 0.038 \\
\hline GCS & $7.6 \pm 5.0$ & $13.2 \pm 3.2$ & 0.003 \\
\hline $\mathrm{GCS}=3$ & $3(42.9 \%)$ & $3(4.8 \%)$ & 0.012 \\
\hline $\mathrm{COHb}$ level (\%) & $20.3 \pm 16.2$ & $19.2 \pm 13.7$ & 0.728 \\
\hline $\mathrm{COHb}$ level $>25 \%$ & $3(42.9 \%)$ & $20(32.3 \%)$ & 0.679 \\
\hline \multicolumn{4}{|l|}{ Tn level $(n g / m L) ~[n=29]$} \\
\hline Mean \pm SD & $2.56 \pm 1.3$ & $0.05 \pm 0.1$ & $<0.001$ \\
\hline Median, IQR & $2.72,2.47$ & $0.02,<0.001$ & \\
\hline $\mathrm{Tn}>0.03 \mathrm{ng} / \mathrm{mL}(\mathrm{n}=29)$ & $4 / 4(100 \%)$ & $3 / 25(12 \%)$ & 0.001 \\
\hline CK (IU/L) [n=41] & & & 0.008 \\
\hline Mean $\pm S D$ & $1830 \pm 1527$ & $855 \pm 2019$ & \\
\hline Median, IQR & 1370,3141 & 127,322 & \\
\hline CK >200 IU/L (n=41) & $5 / 6(83.3 \%)$ & $12 / 35$ (34.3\%) & 0.066 \\
\hline ECG changes & $1 / 6(16.7 \%)$ & $3 / 60(5 \%)$ & 0.22 \\
\hline Intubation & $4(57.1 \%)$ & $6(9.7 \%)$ & 0.007 \\
\hline Co-ingestion & $4(57.1 \%)$ & $31(50.0 \%)$ & 1.000 \\
\hline
\end{tabular}

Abbreviations: $\mathrm{BP}=$ blood pressure; $\mathrm{CK}=$ creatine kinase; $\mathrm{COHb}=$ carboxyhaemoglobin; DNS = delayed neurological sequelae; ECG = electrocardiogram; GCS = Glasgow Coma Scale score; HBOT = hyperbaric oxygen therapy; IQR = interquartile range;

$\mathrm{LOC}=$ loss of consciousness; SD = standard deviation; $\mathrm{Tn}=$ troponin

* Unless otherwise indicated 
statistically significant $(\mathrm{P}=0.184)$.

In order to identify possible prognostic factors for DNS development and to eliminate the possible effect of HBOT, a second comparative analysis was performed between the DNS group and non-DNS group after excluding those patients treated by HBOT (Table 4). This second analysis showed that when compared with the non-DNS group, the DNS group had a significantly greater proportion of patients with LOC and GCS score of 3, lower GCS score, higher levels of Tn and CK, higher proportion of patients with elevated Tn, and higher tendency to have been intubated.

Since the HBOT group did not develop DNS and the DNS group did not receive HBOT, another univariate analysis was performed to detect any significant difference between these two groups (Table 5). This showed that the DNS and HBOT groups were similar for all the above tested variables, except for the Tn level that was significantly higher in the DNS group. The proportion of patients with elevated Tn was similar for the two groups, however.

\section{Discussion}

\section{Pathophysiology of carbon monoxide poisoning}

Carbon monoxide is a colourless, odourless, nonirritating but highly toxic gas produced during incomplete carbon combustion. A small amount of $\mathrm{CO}$ is produced after degradation of heme physiologically in human body. ${ }^{9}$ Poisoning of $\mathrm{CO}$ develops only after the dose exceeds the elimination capacity. The elimination half-life of $\mathrm{COHb}$ in humans is approximately 208 to 358 minutes in room air, ${ }^{10} 74$ minutes in normobaric oxygen therapy, ${ }^{11}$ and 20 minutes in 3 atmosphere absolute pressure of HBOT. ${ }^{12}$ Carbon monoxide binds to haemoglobin, myoglobin, and cytochrome oxidase with an affinity of 200 to 300 times, 30 to 60 times, and 9 times more than oxygen, respectively. The decrease in oxygen carrying and delivery capacity of blood results in tissue hypoxia. ${ }^{13}$ Cellular hypoxia causes the release of free radicals that bind with nitric oxide (NO) from heme to produce peroxynitrite $\left(\mathrm{ONOO}^{-}\right)$, further

TABLE 5. Comparative univariate analysis of DNS and HBOT groups

\begin{tabular}{|c|c|c|c|}
\hline & \multicolumn{2}{|c|}{ Mean \pm SD or No. (\%) of patients* } & \multirow[t]{2}{*}{$P$ value } \\
\hline & DNS (n=7) & HBOT (n=24) & \\
\hline Age (years) & $36.9 \pm 16$ & $36.3 \pm 12$ & 0.554 \\
\hline Male & $57.1 \%$ & $50 \%$ & 1.000 \\
\hline Systolic BP (mm Hg) & $117 \pm 35$ & $120 \pm 21$ & 0.421 \\
\hline Diastolic BP (mm Hg) & $70 \pm 15$ & $77 \pm 15$ & 0.298 \\
\hline Heart rate (beats/min) & $104 \pm 23$ & $104 \pm 22$ & 0.554 \\
\hline Temperature $\left({ }^{\circ} \mathrm{C}\right)$ & $37.6 \pm 1.4$ & $36.4 \pm 0.9$ & 0.087 \\
\hline LOC & $6(85.7 \%)$ & $21(87.5 \%)$ & 1.000 \\
\hline GCS & $7.6 \pm 5.0$ & $8.3 \pm 4.7$ & 0.599 \\
\hline $\mathrm{GCS}=3$ & $3(42.9 \%)$ & $5(20.8 \%)$ & 0.335 \\
\hline COHb level (\%) & $20.3 \pm 16.2$ & $27.8 \pm 13.7$ & 0.288 \\
\hline $\mathrm{COHb}$ level $>25 \%$ & $3(42.9 \%)$ & $15(62.5 \%)$ & 0.413 \\
\hline \multicolumn{4}{|l|}{ Tn level (ng/mL) [n=23] } \\
\hline Mean $\pm S D$ & $2.56 \pm 1.3$ & $1.10 \pm 2.6$ & 0.015 \\
\hline Median, IQR & $2.72,2.47$ & $0.37,0.538$ & \\
\hline $\mathrm{Tn}>0.03 \mathrm{ng} / \mathrm{mL}(\mathrm{n}=23)$ & $4 / 4(100 \%)$ & 15/19 (78.9\%) & 1.000 \\
\hline \multicolumn{4}{|l|}{ CK (IU/L) [n=26] } \\
\hline Mean \pm SD & $1830 \pm 1527$ & $5178 \pm 16383$ & 0.224 \\
\hline Median, IQR & 1370,3141 & 446,2402 & \\
\hline CK >200 IU/L $(n=26)$ & $5 / 6(83.3 \%)$ & $13 / 20(65 \%)$ & 0.628 \\
\hline ECG changes & 1/6 (16.7\%) & $5 / 24(20.8 \%)$ & 0.166 \\
\hline Intubation & $4(57.1 \%)$ & $15(62.5 \%)$ & 1.000 \\
\hline Co-ingestion & $4(57.1 \%)$ & $9(37.5 \%)$ & 0.413 \\
\hline
\end{tabular}

Abbreviations: $\mathrm{BP}=$ blood pressure; $\mathrm{CK}=$ creatine kinase; $\mathrm{COHb}=$ carboxyhaemoglobin; DNS = delayed neurological sequelae; $\mathrm{ECG}$ = electrocardiogram; GCS = Glasgow Coma Scale score; HBOT = hyperbaric oxygen therapy; IQR = interquartile range; LOC = loss of consciousness; SD = standard deviation; $T \mathrm{n}=$ troponin

* Unless otherwise indicated 
inhibiting cytochrome oxidase and resulting in DNA damage and apoptosis. ${ }^{14-16}$

The clinical presentation of 'cherry-like' skin discolouration is secondary to the red colour of $\mathrm{COHb}$ and $\mathrm{CO}$-induced vasodilation. Headache from $\mathrm{CO}$ poisoning is likely mediated by extracerebral and intracerebral vasodilation with displacement of NO from heme by CO. ${ }^{15,17}$ On the other hand, DNS is likely to be caused by the combination of $\mathrm{COHb}$, mitochondrial oxidative stress, $\mathrm{NO}, \mathrm{ONOO}^{-}$, oxygen free radicals, apoptosis, immune-mediated injury, inflammatory response, brain lipid peroxidation, and other unknown mechanisms. ${ }^{13-22}$

\section{Delayed neurological sequelae}

There is no universal agreed definition of DNS following $\mathrm{CO}$ poisoning. It is typically preceded by a lucid period of 2 to 40 days after the initial poisoning. ${ }^{20}$ Clinical manifestations range from impairment of concentration, attention, learning, memory, language and motor function, as well as psychiatric functions such as depression, dementia, psychosis and mutism, to neurological dysfunction such as paralysis, convulsion, urine or faecal incontinence, gait disturbance, and Parkinson-like syndrome.

According to the uniqueness of the health care system in Hong Kong, there is more than a 90\% chance that patients with severe DNS will rely on the public sector for further management. In addition, all cases were analysed for detection of DNS until December 2014 in this study. All cases were followed up by CMS record for more than 1 year, thus most patients in this cohort who developed severe DNS should have been captured. Contrary to the current belief that onset of DNS development ranges typically from a few days to a few weeks, ${ }^{23}$ this study showed that DNS might present as late as 6 months to 1 year after the index $\mathrm{CO}$ poisoning. Regular follow-up is required to detect the onset of DNS. Further studies are necessary to determine the optimum follow-up duration for DNS.

All seven DNS cases illustrated that DNS secondary to $\mathrm{CO}$ poisoning can be very debilitating to both patients and their caretakers. Of 93 patients, only 55 (59.1\%) were followed up in our psychiatric unit. None of the 93 patients with $\mathrm{CO}$ poisoning were followed up in our medical unit. No mild-tomoderate case of DNS was reported in this study, probably due to the absence of a standardised treatment protocol and formal neuropsychiatric tests for detection of DNS secondary to $\mathrm{CO}$ poisoning. It is therefore likely that cases of mild-to-moderate DNS are underdiagnosed and under-reported in Hong Kong. In order to diagnose DNS secondary to $\mathrm{CO}$ poisoning, a standardised treatment protocol with adequate follow-up and neuropsychiatric tests is recommended.
We identified the following prognostic factors associated with DNS development in patients with severe CO poisoning: LOC, lower GCS score, GCS score of 3 , intubation requirement, elevated Tn level, and higher levels of Tn and CK. Other investigational prognostic markers reported worldwide include S100B protein, ${ }^{24}$ low Mini-Mental State Examination score, ${ }^{25}$ positive computed tomography of brain, ${ }^{25,26}$ and plasma copeptin. ${ }^{27}$

The results of this study reveal that severe DNS did not develop in any patient with severe CO poisoning who was treated with HBOT at PYNEH between 2008 and 2013. Although the results did not reach statistical significance due to limited sample size, this $100 \%$ protective effect indicates a potential clinical benefit of HBOT to prevent severe DNS in patients with severe $\mathrm{CO}$ poisoning. In order to look for potential selection bias between the DNS group and HBOT group, comparative univariate analysis between the DNS and HBOT groups was performed (Table 5). The DNS groups and HBOT groups were similar in terms of the initial presentation. Although the magnitude of Tn level in the DNS group (2.56 $\pm 1.3 \mathrm{ng} / \mathrm{mL}$ ) was statistically greater than that of HBOT group $(1.10 \pm 2.6 \mathrm{ng} / \mathrm{mL})$ with a $P$ value of 0.015 , it was not clinically significant in terms of patient management. The sole different factor was the treatment of HBOT. It is strongly suggested that HBOT prevents DNS development in severe $\mathrm{CO}$ poisoning.

The role of HBOT in the management of patients with $\mathrm{CO}$ poisoning remains controversial with conflicting results from large randomised controlled trials. All trials have been criticised for bias, thus there has been a pledge for a betterdesigned trial with multicentre participation. Nonetheless ethical, financial, and practical issues associated with most clinical toxicology studies make such a trial unlikely in the near future. The results of this study did show clinical significance despite a statistically insignificant result. Current literature supports the potential of HBOT to prevent or treat DNS resulting from CO poisoning. ${ }^{2,4-7,22}$ On balance, HBOT should be considered for all patients at risk of development of neurological sequelae. ${ }^{22}$

In Hong Kong, HBOT has been underutilised in public hospitals because of the unavailability of hospital-based hyperbaric chambers. Most patients in Hong Kong with severe $\mathrm{CO}$ poisoning do not receive HBOT because of the risks of transporting a critically ill patient to Ngong Shuen Chau, the inadequacy of intensive care support in the hyperbaric chamber of Ngong Shuen Chau, occupational hazards, beliefs of individual health care providers, and availability of expertise. A hospital-based hyperbaric oxygen chamber is essential to decrease the burden of HBOT and provide timely treatment in a safe environment 
for patients with severe $\mathrm{CO}$ poisoning.

Records retrieved from CDARS for the period 2003 to 2013 revealed 1451 patients with $\mathrm{CO}$ poisoning who presented to HA hospitals. This indicates that approximately two patients with $\mathrm{CO}$ poisoning presented to hospitals every 5 days over the last 10 years. According to the indications for HBOT adopted in this study, the percentage of patients in whom HBOT was indicated was $67.7 \%$ (63/93). Assuming three sessions of HBOT would have been required for each patient and the percentage of patients requiring HBOT over the last 10 years was $67.7 \%$, it can be estimated that 295 sessions of HBOT would have been required by patients treated in HA hospitals (1451 patients $\mathrm{x}$ $67.7 \%$ x 3 sessions / 10 years $=295$ ). If a hyperbaric oxygen chamber is available in a public hospital, more patients with $\mathrm{CO}$ poisoning can be treated in a safe and controlled environment. Suppose the incidence of DNS in Hong Kong is similar to that worldwide (10\%-30\%), then 145 to 435 instances of DNS may have been potentially prevented in these 10 years. In addition, the length of stay in hospital may have been significantly decreased.

\section{Limitations}

First, selection bias existed in this study although diagnosis coding entry has been compulsory in the accident and emergency department of PYNEH since 2008. It is possible that some patients with $\mathrm{CO}$ poisoning were admitted with another principal diagnosis and discharged without coding of $\mathrm{CO}$ poisoning. If this is the case, then not all patients with $\mathrm{CO}$ poisoning during the study period were retrieved in this study. This was a single-centre study and results might not be applicable to all patients with CO poisoning in Hong Kong. Second, there was information bias due to its retrospective nature. Not all patients were investigated with $\mathrm{Tn}, \mathrm{CK}$, and ECG leading to potential bias. The time of investigations and oxygen treatment given to patients were not standardised giving rise to difficulty in interpretation of a relatively low $\mathrm{COHb}$ level at presentation. In addition, no neuropsychiatric tests were performed to detect any DNS after CO poisoning, resulting in underdiagnosis of DNS. The strength in information bias is the outcome measurement of DNS and laboratory results that provide an objective measure, unlike a questionnaire. Third, confounding bias was inevitable as $45.2 \%$ of patients had co-ingestion of medications or alcohol. This might have influenced the initial clinical presentation as well as the results. Subgroup analysis of different medications was not shown because of the diversities and complexity without significant results. Lastly, despite the length of the study period, the sample size was inadequate to provide statistically significant results.

\section{Conclusion}

Although not statistically significant, this study showed $100 \%$ protective effect of HBOT against development of severe DNS in patients with severe $\mathrm{CO}$ poisoning. Further study with better study design is warranted. This study revealed that LOC, low GCS score, intubation requirement, elevated Tn and higher CK levels were possible prognostic factors for development of DNS. As there was no standardised treatment protocol and no formal follow-up arranged for detection of DNS in patients with severe $\mathrm{CO}$ poisoning, mild-to-moderate DNS was probably underdiagnosed and under-reported in Hong Kong. A well-defined treatment protocol, appropriate follow-up duration, and neuropsychiatric tests together with a hospital-based hyperbaric chamber are recommended for management of patients with severe $\mathrm{CO}$ poisoning.

\section{Declaration}

No conflicts of interest were declared by the authors.

\section{References}

1. Chan KP, Yip PS, Au J, Lee DT. Charcoal-burning suicide in post-transition Hong Kong. Br J Psychiatry 2005;186:6773.

2. Raphael JC, Elkharrat D, Jars-Guincestre MC, et al. Trial of normobaric and hyperbaric oxygen for acute carbon monoxide intoxication. Lancet 1989;2:414-9.

3. $\mathrm{Hu} \mathrm{H}$, Pan X, Wan Y, Zhang Q, Liang W. Factors affecting the prognosis of patients with delayed encephalopathy after acute carbon monoxide poisoning. Am J Emerg Med 2011;29:261-4.

4. Scheinkestel CD, Bailey M, Myles PS, et al. Hyperbaric or normobaric oxygen for acute carbon monoxide poisoning: a randomised controlled clinical trial. Med J Aust 1999;170:203-10.

5. Thom SR, Taber RL, Mendiguren II, Clark JM, Hardy KR, Fisher AB. Delayed neuropsychologic sequelae after carbon monoxide poisoning: prevention by treatment with hyperbaric oxygen. Ann Emerg Med 1995;25:474-80.

6. Weaver LK, Hopkins RO, Chan KJ, et al. Hyperbaric oxygen for acute carbon monoxide poisoning. N Engl J Med 2002;347:1057-67.

7. Buckley NA, Juurlink DN, Isbister G, Bennet MH, Lavonas EJ. Hyperbaric oxygen for carbon monoxide poisoning. Cochrane Database Syst Rev 2011;(4):CD002041.

8. Lam KK, Fung HT, Kam CW. The severity and prognostic markers of 148 cases of carbon monoxide poisoning by burning charcoal. Hong Kong J Emerg Med 2006;13:6-16.

9. Owens EO. Endogenous carbon monoxide production in disease. Clin Biochem 2010;43:1183-8.

10. Bruce EN, Bruce MC. A multicompartment model of carboxyhemoglobin and carboxymyoglobin responses to inhalation of carbon monoxide. J Appl Physiol (1985) 2003;95:1235-47.

11. Weaver LK, Howe S, Hopkins R, Chan KJ. Carboxyhemoglobin half-life in carbon monoxidepoisoned patients treated with $100 \%$ oxygen at atmospheric 
pressure. Chest 2000;117:801-8.

12. Peterson JE, Stewart RD. Absorption and elimination of carbon monoxide by inactive young men. Arch Environ Health 1970;21:165-71.

13. Coburn RF, Mayers LB. Myoglobin oxygen tension determines from measurements of carboxyhemoglobin in skeletal muscle. Am J Physiol 1971;220:66-74.

14. Zhang J, Piantadosi CA. Mitochondrial oxidative stress after carbon monoxide hypoxia in the rat brain. J Clin Invest 1992;90:1193-9.

15. Thom SR, Ohnishi TS, Ischiropoulos H. Nitric oxide release by platelets inhibits neutrophil B2 integrin function following acute carbon monoxide poisoning. Toxicol Appl Pharmacol 1994;128:105-10.

16. Hardy KR, Thom SR. Pathophysiology and treatment of carbon monoxide poisoning. J Toxicol Clin Toxicol 1994;32:613-29.

17. Thom SR, Fisher D, Xu YA, Garner S, Ischiropoulos H. Role of nitric oxide-derived oxidants in vascular injury from carbon monoxide in the rat. Am J Physiol 1999;276:H984-92.

18. Thom SR. Carbon monoxide-mediated brain lipid peroxidation in the rat. J Appl Physiol (1985) 1990;68:9971003.

19. Thom SR. Dehydrogenase conversion to oxidase and lipid peroxidation in brain after carbon monoxide poisoning. J Appl Physiol (1985) 1992;73:1584-9.
20. Thom SR. Antagonism of carbon monoxide-mediated brain lipid peroxidation by hyperbaric oxygen. Toxicol Appl Pharmacol 1990;105:340-4.

21. Thom SR, Bhopale VM, Fisher D, Zhang J, Gimotty P. Delayed neuropathology after carbon monoxide poisoning is immune-mediated. Proc Natl Acad Sci USA 2004;101:13660-5.

22. Weaver LK. Clinical practice: carbon monoxide poisoning. N Engl J Med 2009;369:1217-25.

23. Choi IS. Delayed neurological sequelae in carbon monoxide intoxication. Arch Neurol 1983;40:433-5.

24. Park E, Ahn J, Min YG, et al. The usefulness of the serum s100b protein for predicting delayed neurological sequelae in acute carbon monoxide poisoning. Clin Toxicol (Phila) 2012;50:183-8.

25. Ku HL, Yang KC, Lee YC, Lee MB, Chou YH. Predictors of carbon monoxide poisoning-induced delayed neuropsychological sequelae. Gen Hosp Psychiatry 2010;32:310-4.

26. Kudo K, Otsuka K, Yagi J, et al. Predictors for delayed encephalopathy following acute carbon monoxide poisoning. BMC Emerg Med 2014;14:3.

27. Pang L, Wang HL, Wang ZH, et al. Plasma copeptin as a predictor of intoxication severity and delayed neurological sequelae in acute carbon monoxide poisoning. Peptides 2014;59:89-93. 